\title{
Interlinking ecosystem services and Ostrom's framework through orientation in sustainability research
}

\author{
$\underline{\text { Stefan Partelow }}^{1,2}$ and Klara J. Winkler ${ }^{3}$
}

\begin{abstract}
Structuring integrated social-ecological systems (SES) research remains a core challenge for achieving sustainability. Numerous concepts and frameworks exist, but there is a lack of mutual learning and orientation of knowledge between them. We focus on two approaches in particular: the ecosystem services concept and Elinor Ostrom's diagnostic SES framework. We analyze the strengths and weaknesses of each and discuss their potential for mutual learning. We use knowledge types in sustainability research as a boundary object to compare the contributions of each approach. Sustainability research is conceptualized as a multi-step knowledge generation process that includes system, target, and transformative knowledge. A case study of the Southern California spiny lobster fishery is used to comparatively demonstrate how each approach contributes a different lens and knowledge when applied to the same case. We draw on this case example in our discussion to highlight potential interlinkages and areas for mutual learning. We intend for this analysis to facilitate a broader discussion that can further integrate SES research across its diverse communities.
\end{abstract}

Key Words: boundary object; knowledge types; social-ecological systems; sustainability science

\section{INTRODUCTION}

Social-ecological systems (SES) thinking represents the coupled interactions and outcomes between human and natural systems (Walker and Salt 2006, Liu et al. 2007, Ostrom 2009). Researchers have developed a variety of concepts and frameworks to help analyze, describe, and communicate SES components and processes (Newell et al. 2005, Binder et al. 2013). Notable developments include the ecosystem services (ES) concept and the diagnostic social-ecological systems framework (SESF). Although both are used in SES research, they lack common structures to orient and compare knowledge between them (Ostrom 2009, Mollinga 2010, Hinkel et al. 2014).

Integrating knowledge between multiple concepts and frameworks is a challenge for building academic consensus that can inform sustainability (Spangenberg 2011, Fischer et al. 2015, Ruppert-Winkel et al. 2015). However, much of the SES literature continues to generate knowledge that is uncoupled from other research efforts. Orienting the contributions within SES research is difficult when knowledge cannot be compared or integrated (Newell et al. 2005, Ostrom 2009, Bohensky and Maru 2011). Without structures for knowledge orientation, opportunities to cobenefit between SES research efforts are missed (Scholz 2011).

For comparative purposes, we categorize the knowledge SES research can generate into three types that can inform sustainability: (1) system knowledge analyzing and describing SES functionality and subsystem processes, (2) target knowledge assessing meaningful goals, visions, and pathways for sustainable human well-being and ecosystem functioning, and (3) transformative knowledge for implementing practical solutions (Hadorn et al. 2006, Jerneck et al. 2010, Brandt et al. 2013).

The goals of SES research are better achieved when knowledge from different research efforts can inform and advance each other (Fischer et al. 2015, Bull et al. 2016). We use the three knowledge types as a boundary object to orient different SES research contributions (Fig. 1). Different combinations of knowledge types will be generated depending on the concept, theory, model, or framework used. However, conducting research that can generate or orient all three knowledge types remains elusive.

Fig. 1. Conceptual interpretation of a circular multistep knowledge development process for social-ecological systems (SES) research. SES research can generate three knowledge types: (1) system knowledge in order to analyze and describe the functionality SES and their subsystem processes, (2) target knowledge to develop meaningful goals, targets, and pathways for sustainable human well-being and ecosystem functioning, and (3) transformative knowledge for implementing those goals into practical solutions (Hadorn et al. 2006, Jerneck et al. 2010, Brandt et al. 2013).

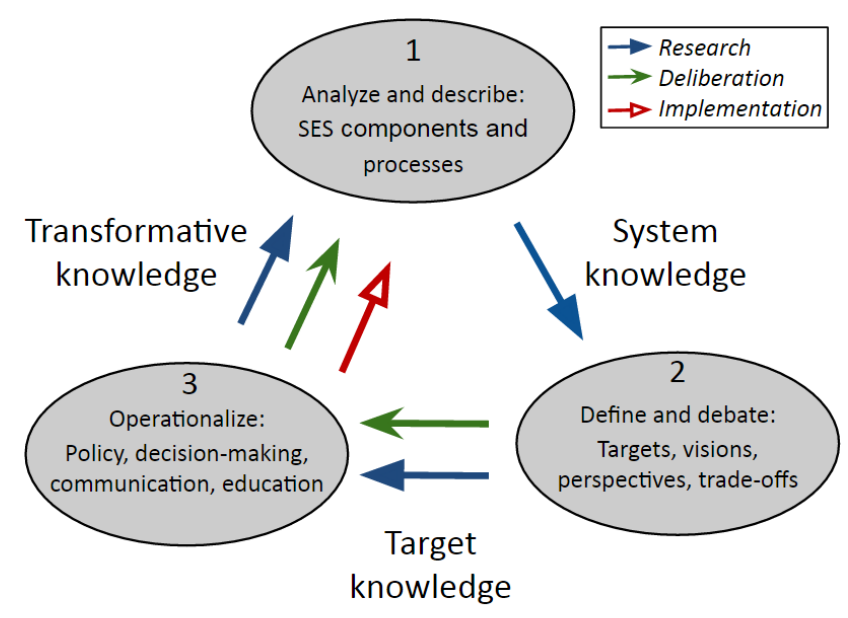

${ }^{1}$ Leibniz Center for Tropical Marine Ecology (ZMT), Bremen, Germany, ${ }^{2}$ Jacobs University, Bremen, Germany, ${ }^{3}$ Carl-von-Ossietzky University Oldenburg, Oldenburg, Germany 
Table 1. Definitions.

System knowledge: objective knowledge of social-ecological subsystems and components, as well as their interactions, functions, processes, and interrelated dynamics; including aspects in relation to risk, uncertainty, and resilience

Target knowledge: subjective perspectives, deliberative, and/or experienced knowledge relating to the implications, targets, visions, desired directions, and outcomes for social-ecological systems (SES); this can include the concepts of human well-being, conservation, justice, ethics, efficiency, and sustainability goals

Transformative knowledge: actionable pathways for implementing SES change and/or target knowledge through normative mechanisms such as policy, decision-making, education, communication, participation, and motivation

SES thinking: recognition for linked and interdependent natural and social system dynamics, particularly human dependence on ecosystems and the need to facilitate multidomain research that engages with nonacademic society to achieve sustainability (Fischer et al. 2015)

Boundary object: "Objects which are both plastic enough to adapt to local needs and the constraints of the several parties employing them, yet robust enough to maintain a common identity across sites." (Star and Griesemer 1989:393; see also Hertz and Schlüter 2015:15)

Ecocentric: consideration of an "ecological system based on its internal functioning" and diverse values (Binder et al. 2013), where human life is dependent on existing and intact ecosystem functioning and biodiversity (Mace 2014)

Anthropocentric: consideration of an ecological system based on its utility for humans (Binder et al. 2013), focused on maintaining the ecological functioning that provides human value

We focus our analysis on comparing and facilitating mutual learning between the ES concept (Millennium Ecosystem Assessment 2005, Haines-Young and Potschin 2012, Díaz et al. 2015) and Elinor Ostrom's diagnostic SES framework (SESF) (Ostrom 2007, 2009, McGinnis and Ostrom 2014). After an overview of the ES concept and the SESF, we orient the contributions of ES and the SESF in facilitating system, target, and transformative knowledge. Next, we compare the two approaches in a case study of the Southern California spiny lobster fishery. Last, we provide a synthesis of both approaches and analyze the potential for mutual learning and compatibilities between them. Definitions of terminology used in this article are provided in Table 1.

\section{OVERVIEW}

Researchers have begun to explore linkages between ES and the SESF in recent studies. Ban et al. (2015) demonstrate how the coconsideration of multiple ES in an analysis structured with the SESF can help better understand complexities in a large-scale marine system. Grêt-Regamey et al. (2014) suggest incorporating Ostrom's tiered structure of multilevel interactions to map ES assessments. In addition, others have used the SESF to diagnose payment for ecosystem services (PES) schemes (e.g., Addison and Greiner 2015, Bennett and Gosnell 2015). Despite preliminary efforts, considerable gaps exist for exploring how the ES concept and the SESF can be used in an integrated analysis. As separate entities, they have been considered as potential boundary objects within SES research (Abson et al. 2014, Hertz and Schlüter 2015, Schleyer et al. 2015).

\section{Ecosystem services}

Since the publication of the Millennium Ecosystem Assessment in 2005, ES research has exponentially expanded through broad usage in ecology and economics (Seppelt et al. 2011, Orenstein 2013, Chaudhary et al. 2015, Luederitz et al. 2015). The concept embodies an ecocentric framing in the sense that humans depend on the services nature provides (Mace 2014). One of the latest conceptualizations, the ES cascade (Fig. 2), shows a multistep process that describes the supply of ES to humans and the reciprocal effects of humans on ecosystems through a governance feedback loop (Haines-Young and Potschin 2010, 2012). The ES cascade is widely discussed (e.g., Spangenberg et al. 2014) and has been further developed (e.g., Martín-López et al. 2014). However, current research focuses largely on the directional flow of ES provided to humans, while human actions affecting ecosystems have received less attention (Comberti et al. 2015, Davies et al. 2015). Additionally, governance mechanisms and institutions that influence the provision and appropriation of ES are sparse (Nassl and Löffler 2015, Primmer et al. 2015).

Numerous ways of using the ES concept have evolved in the literature. The economic approach is the most widely recognized, including, for example, the TEEB (2010) report and PES schemes, which mostly try to internalize external effects. However, ES research is manifold, and thus it is shortsighted to limit the potential of the concept to a purely economic perspective (Schröter and van Oudenhoven 2016). The ES concept can serve as a communication tool to engage the science-policy-society interface (Díaz et al. 2015, Everard 2015, Bull et al. 2016).

\section{Ostrom's diagnostic social-ecological systems framework}

The SESF is a diagnostic checklist of potential interacting SES components with multitiered nested relationships to each other (Ostrom 2007, 2009, Frey and Cox 2015, Hinkel et al. 2015). The framework is tailored for, but not limited to, understanding collective action in a shared common-pool resource system. The framework's ontology is organized into four subsystems: the resource system, resource units, governance, and actors (Fig. 2). Externally, these four subsystems interact with the social, economic, and political settings, and related ecosystems. Action 
Fig. 2. Side-by-side comparison of the ecosystem services (ES) cascade (left: adapted from Martín-López et al. 2014) and diagnostic SES framework (SESF) (right: McGinnis and Ostrom 2014). Both conceptual frameworks focus on the interactive processes between social (blue) and ecological (green) subsystems. There are more specific components that are nested within the categories of each, but they are not shown here.

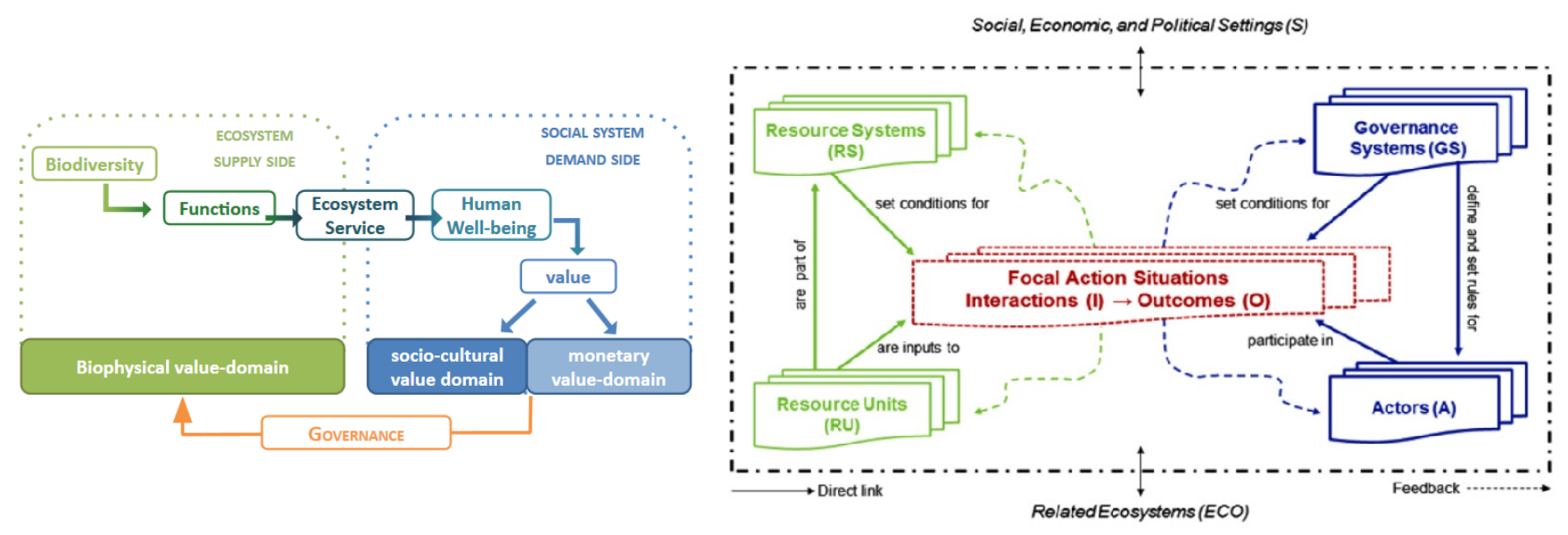

situations occur when components in the SES create interactions that shape outcomes (Ostrom 2007, 2009). Action situations originate from the Institutional Analysis \& Development (IAD) framework, where sets of criteria and rules theoretically frame social-institutional processes to distil individual and group decision-making (Ostrom 2005, McGinnis and Ostrom 2014). Social-ecological systems can have polycentric interactions, with multiple action situations occurring simultaneously (McGinnis 2011).

The SESF is envisioned to serve two reinforcing purposes: first, to contextually diagnose complex SES cases through a common and structured language; second, to generate comparable data that can use large- $\mathrm{N}$ case comparisons to explore commonalities across case studies for theory generation and policy. The framework does not provide a methodology for empirical data collection, but rather a common structure to orient collected data into a comparable SES language. Guidelines for operationalizing research with the SESF and further developing the framework for use in specific sectors has been suggested (e.g., Delgado-Serrano and Andres Ramos 2015, Leslie et al. 2015, Marshall 2015, Partelow 2015).

\section{ORIENTING KNOWLEDGE IN SUSTAINABILITY RESEARCH}

\section{System knowledge}

System knowledge is the "classic" knowledge produced by science. This is objective research for understanding system components, functional processes, and interrelated dynamics as a foundational base. The development of system knowledge is often a descriptive methodological and analytical process that does not require the development of normative direction, communication, or practical engagement beyond the discourse of science.

There is a vast body of literature that has generated system knowledge in ES research. Although the ES concept has always stressed the human-nature relationship, so far, most research has focused on a single or small set of ES. Most of the methods used to identify and describe ES originate from the fields of ecology and economics (Seppelt et al. 2011). Such technocratic approaches often favor easily quantifiable ES such as crop provisions or flood protection (Reyers et al. 2013, Turnhout et al. 2013). When limited by easily quantifiable ES, the approach produces primarily system knowledge. In contrast, less tangible ES are often neglected due to difficulties in interpreting data through measurable indicators (Milcu et al. 2013, Fagerholm et al. 2016). Nevertheless, scientific-technical research plays a crucial role in the governance of ecosystems and their ES (Primmer et al. 2015). For example, system knowledge that identifies trade-offs between different ES and their effects on ecosystems is important for practitioners to make informed decisions (de Groot et al. 2010).

The primary strength of the SESF is in generating system knowledge through a diagnostic approach. This can be compared to medical practice; for example, when a physician diagnoses the ill health of a patient by identifying the components and processes of the body that may be causing the problem, typically through indicators such as body temperature and blood pressure. The SESF currently has more than 50 components and interactions, which act as a checklist, to diagnose sustainability problems in a SES (McGinnis and Ostrom 2014). Using the framework involves gathering data that can describe the characteristics of each component, if present, and how they interact and shape system processes. For some components, indicators that contextually represent the component in a system may need to be developed. The SESF suggests components that might be important for system outcomes; e.g., property rights. However, it does not claim that a particular state or status of a component leads to certain outcomes. Thus, the framework does not incorporate theory to link system conditions to outcomes, but it provides a common structure of components that can be used to generate theory when system conditions and outcomes are identified (Ostrom and Cox 2010). The usefulness of the framework will vary depending on 
the depth of data gathered to describe the system conditions through its suggested components and processes. Adding components and processes to the SESF is likely necessary through further empirical investigations that can identify the relationships between new and existing components in different contexts (Frey and Cox 2015). Overall, facilitating structured system knowledge with consideration for broad social and ecological components is a strength of the framework.

\section{Target knowledge}

Social-ecological systems research is suitably positioned to move beyond the generation of system knowledge and to transition research into a more active role in society (Fischer et al. 2015). This transition will generate target knowledge. Building on system knowledge, target knowledge captures the subjective perceptions, goals, and visions that shape a normative direction. This can include the concepts of ethics, morality, and justice. Without this knowledge, there is the possibility that decision-makers hold a great amount of system knowledge but lack the ability to translate that knowledge into socially relevant and accepted decisions. Informing decision-making and planning processes with target knowledge aids the inclusion of stakeholder perspectives and increases the acceptance of (sometimes unpopular) measures (Scholz and Steiner 2015). Robust and contextually relevant target knowledge is important for successful adaptive governance approaches (Gadgil et al. 1993) and long-lasting solutions (Millennium Ecosystem Assessment 2005).

The generation of knowledge about diverse societal perspectives on ES is less developed compared to ecological aspects (Davies et al. 2015). However, ES researchers have realized that sustainable solutions cannot be based solely on system knowledge, but that there is high relevance for the inclusion of norms, values, and subject perspectives related to ES demand (Görg et al. 2014, Jordan and Russel 2014, Primmer et al. 2015). Specifically, the ES concept attributes values to biophysical, socio-cultural, and monetary value domains (Fig. 2). Cultural ES recognize the social and relational values gained from ecosystems (e.g., sense of place or recreation), which allows subjectivity to enter ES assessments and valuations (Chan et al. 2012b, 2016, Daniel et al. 2012). In addition, social-cultural valuation is often conducted through participatory methods (Scholte et al. 2015, Winkler and Nicholas 2016) (Fig. 3). Local-level research projects are well situated for assessing target knowledge due to the more iterative nature of the process between the producers and users of ES knowledge (Haines-Young and Potschin 2014, Förster et al. 2015).

The SESF has numerous components, including action situations, that facilitate target knowledge generation. However, the SESF is more diagnostic and analytical than value oriented (Fig. 3). The diagnosis of action situations identifies social-ecological processes, driven almost entirely from the social system side in the SESF, such as deliberation, investments, self-organization, lobbying, and information sharing (McGinnis and Ostrom 2014). Understanding action situations is in part dependent on target knowledge - why stakeholders make decisions based on their goals and values. There are two types of action situations: (1) an appropriation action situation, where actors face a collective action challenge to avoid overuse of a resource, good, or service; and (2) a provisioning action situation, where actors face a collective action challenge to provide, maintain, or create a resource, good, or service (Hinkel et al. 2015). Either situation could be influenced by numerous actor characteristics that should be acknowledged in a diagnosis. Many diagnostic components of the SESF nested in the first tier actor subsystem facilitate target knowledge. These include social norms/capital, mental models/ knowledge of SES, and leadership, among others. Individual and community values as well as perceptions toward society and the environment will be understood through conducting descriptive research on such components.

Fig. 3. Conceptual orientation of the ecosystem services concept and the social-ecological systems framework showing their generalized contributions to generating each type of knowledge. Each approach is crudely placed on the scale of each knowledge type as an interpretation of their relationship.
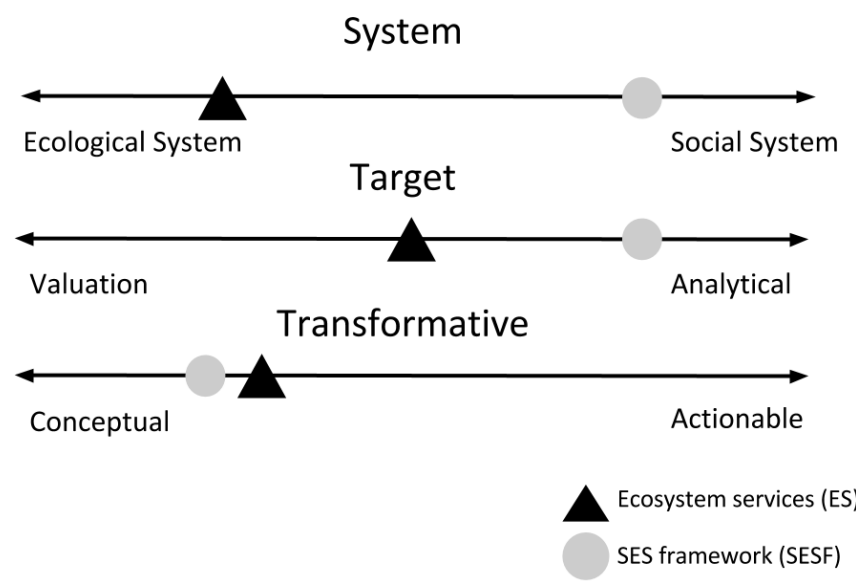

\section{Transformative knowledge}

Transformative knowledge informs contextually relevant change pathways toward a desired (target) SES state (Jerneck et al. 2010, Brandt et al. 2013, Abson et al. 2014). It is often generated in a transdisciplinary setting, incorporating multiple academic domains and societal perspectives in the research process (Scholz and Steiner 2015). Transformative knowledge results from the coupled analysis of system and target knowledge. In sustainability science, this aims to transition academic contributions toward implementing practical solutions for society. A vision for SES research is to progress the ambitions of sustainability science (Bodin and Crona 2009, Scholz and Steiner 2015, Schoon and van der Leeuw 2015). However, research on transformational change remains primarily conceptual, particularly regarding political and socio-cultural engagement.

So far, little research has been published on transformative knowledge production within ES. Often it is assumed that existing system knowledge will lead to policy or management decisions that change the unfavorable status of ES, but this has not proven effective (Primmer et al. 2015). However, the ES concept can serve as an approach to motivate innovations (Haines-Young and Potschin 2014). It engages different disciplines and nonacademic stakeholders through a neutral language that has not yet been "captured" from any interest group (Abson et al. 2014, Davies et al. 2015, Everard 2015). Studies using the concept in real-world 
situations show the usefulness of the approach when working with practitioners and individuals. In the landscape planning context, it helps various stakeholders understand different perspectives and demonstrate their own needs (Hauck et al. 2013, Karrasch et al. 2014).

The SESF can facilitate the diagnosis of SES components that can inform transformative knowledge. However, the SESF has not been discussed in the literature or used empirically as a tool for facilitating practical change processes. The primary potential exists to analyze the linkages between system and target knowledge through empirical investigation of the framework's components in a case study. This flow of knowledge toward transformative change (Fig. 1) can be achieved only through indepth knowledge of the case study context. Additionally, there is potential for the SESF to act as a common language or medium for information exchange between researchers, stakeholders, and practitioners or policy-makers, and as a framework for actualizing the ambitions of sustainability science (Partelow 2016). Delgando-Serrano and Ramos (2015) show that the SESF was useful for communicating codesigned SES research and identifying shortcomings of the process at the local level with stakeholders. However, these ambitions remain largely conceptual within the broader literature.

\section{COMPARING APPROACHES IN A CASE STUDY: THE SOUTHERN CALIFORNIA SPINY LOBSTER FISHERY}

In this section, we use the Southern California spiny lobster fishery to compare the differences between ES and the SESF (Fig. 2) when applied to the same case. We demonstrate how each can facilitate the generation of different knowledge types (Tables 2 and 3). By using both approaches, the analysis of the lobster fishery is shown through two lenses. Similarities, differences, and potential for mutual learning are highlighted.

The Southern California spiny lobster fishery is located in the Pacific Ocean along the southwest United States. The broader area is part of the Southern California coastal marine zone, which extends south across the Mexican border into Baja California. The fishery can be referred to as small scale, and has six stakeholder groups: commercial (C), recreational (R), nonconsumptive $(\mathrm{N})$, environmental $(\mathrm{E})$, marine science $(\mathrm{M})$, and federal government $(\mathrm{G})$. There are approximately 150 commercial fishing licenses and more than 30,000 recreational fishing licenses (Partelow and Boda 2015). The spiny lobster (Panulirus interruptus) habitat is embedded in a diverse coastal zone, including intertidal, sandy beach, rocky reef, and seagrass habitat. The coastal zone includes extensive conservation and habitat restoration efforts, generates revenue from tourism, and is an embedded feature of the Southern California cultural identity. A comanagement committee was formed between the stakeholder groups, and was mandated and facilitated by the California Department of Fish and Wildlife to generate sustainable policy recommendations for the state legislature.

The ES approach provides an ecocentric understanding of the fishery. The ecosystem provides a diverse range of goods and services, including lobster and many others. Lobsters are a part of the larger ecological system; they play a role in the maintenance of the ecosystem functions and the biodiversity (Table 2). Lobsters are of central focus for management, but there is a diverse range of other ES also provided to different stakeholders and opportunities for human well-being. Among the different stakeholders, socio-cultural and relational values from the ecosystem and the lobsters are derived both directly and indirectly.

Currently, the ES cascade does not provide a standardized analysis of the functional components of governance. This is the feedback loop connection from the social system to the ecological system (Fig. 2). Other ES approaches are needed to allow for a useful social system analysis as its own entity (e.g., Chan et al. 2012a, Díaz et al. 2015). As a result, ecological system knowledge as well as target knowledge can be facilitated primarily on the values and potential trade-offs that exist between stakeholder groups (Table 2). The basic facilitation of identifying social system components beyond values is absent. Transformative knowledge on reconciling trade-offs in policy can be facilitated but is limited to conceptual interpretation due to a lack of concrete social system components to analyze within the ES cascade.

The SESF diagnosis highlights many components that are influential and interacting in the fishery. The fishery has characteristics of a common-pool resource system, with high rivalry and nonexcludability (Partelow and Boda 2015). The resource has a high economic value, and a comanagement committee with diverse actors groups was identified to deliberate sustainable policy recommendations (Table 3). The ecological system is described in its basic elements as highly productive and large in size with multiple levels of unclear system boundaries in the social and ecological system. The primary action situations affecting fishery outcomes are deliberation and information sharing in the comanagement committee (Table 3). Target knowledge on actor perspectives and goals is combined with system knowledge on the functional structure of the comanagement committee to aid in an analysis of transformative pathways through the action situations that affect the SES outcomes.

\section{INTERLINKAGES AND MUTUAL LEARNING}

In this section, we discuss the strengths and weaknesses of facilitating mutual learning and interlinkages in both approaches. The application of the case study in the Southern California spiny lobster fishery is used to provide examples for our analysis. We frame five key points where interlinkages or mutual learning can be facilitated: (1) broadening the range of value domains in the SESF, (2) expanding the diagnosis of ecosystem functioning in the SESF, (3) describing and analyzing social systems in ES, (4) structuring a common language and framework in ES, and (5) mutual challenges and improvements needed in both approaches.

\section{Broadening the range of value domains in the social-ecological systems framework}

A weakness of the SESF is a lack of recognition of more diverse value domains attributed to resource units, the resource system, and actors. Currently, economic value of the resource unit is the only explicitly recognized value that is diagnosed as influential. Thus, the SESF does not consider broader values of the resource system or resource unit, such as the biophysical, socio-cultural, or relational values recognized in the ES concept (Martín-López et al. 2014, Chan et al. 2016). Learning from how the ES concept recognizes multiple value domains can enhance the diagnostic capacity of the SESF. Socio-cultural values related to the resource 
Table 2. A demonstrative assessment of the Southern California spiny lobster fishery using the ecosystem services (ES) concept. Steps of the ES cascade are matched with case study data from the fishery and the knowledge types generated. Stakeholder groups: commercial $(C)$, recreational $(R)$, non-consumptive $(N)$, environmental $(E)$, marine science $(M)$, and government $(G)$.

Cascade step (Fig. 2)

Southern California spiny lobster fishery

Knowledge types

Biodiversity/ ecosystem functions

Species diversity and functional role

Carrying capacity

System - understanding of the ecological functioning

Habitat of the system

Biomass production

Reproduction dynamics

Ecosystem services (based on Common International Classification of Ecosystem Services)

Provisioning

Lobsters and fish (food)

Kelp (materials)

Cooling water for energy production (energy)

System - assessment of existence and status of ecosystem services

Regulating and maintenance

Coastal upwelling (hydrological cycle)

Salinity and temperature fluctuations (biophysical conditions)

Pollution from urban runoff

Micro and regional climate regulation

Maintaining habitats

Cultural

Sense of place (physical and experiential interactions)

Recreation

Intellectual and representative interactions

Symbolic

Human well-being (based on Chan et al. 2012a)

+/- Material and employment: economic opportunity (C)

$+/$ - Activity and identity: socio-cultural opportunity $(\mathrm{R}, \mathrm{N})$

+ - Existence/bequest: environmental health (E)

+/- Knowledge: scientific scrutiny and impact (M)

+/- Social capital and cohesion: public interest/legality $(\mathrm{G})$

Target - identification of perceived ES benefits for well-being

Governance (based on Díaz et al. 2015)

Decision-making

Power

Responsibilities

Formal (e.g., property rights, treaties, legislation)

and informal (social norms and rules) institutions

Scale (local to global)

Degree of legitimacy, fairness, rights

system can play a large role in decision-making processes for resource management, and can contribute to the development of stakeholder perspectives (Ban et al. 2013). Reciprocally, neglecting biophysical values in natural resource management can degrade the functional integrity of ecosystems through lack of recognition. Adding new components to the framework requires consideration of the nested relationships within the frameworks structure (Frey and Cox 2015). We suggest that the second tier component, "economic value," in the SESF could be replaced with "values." Subsequent third tier components could include biophysical, socio-cultural, and economic values. Market and strategic values have been suggested at the third tier level
(Delgado-Serrano and Andres Ramos 2015). Because values can likely be attributed to the resource system and actor subsystems as well (Fig. 2), there is a need to consider how and where the inclusion of value components can enhance the framework beyond the recognition of dynamics that are centered on the resource units. The facilitation of more target knowledge would likely result.

It is evident that the SESF diagnosis is missing key value domains that play an integral role in shaping stakeholder perspectives on the comanagement committee of the lobster fishery. Sociocultural and relational values influence the main action situations that affect system outcomes, deliberation, and information 
Table 3. A demonstrative diagnosis of the Southern California spiny lobster fishery using the social-ecological systems framework (SESF). First tier subsystems from the SESF are shown (Fig. 2). Data from the fishery and the knowledge types developed are indicated. This table represents a subset of data taken from the full diagnosis of the fishery by Partelow and Boda (2015). Stakeholder groups: commercial (C), recreational (R), non-consumptive $(\mathrm{N})$, environmental (E), marine science (M), and government (G).

\begin{tabular}{|c|c|c|}
\hline $\begin{array}{l}\text { SESF } 1^{\text {st }} \text { tier } \\
\text { (Fig. 2) }\end{array}$ & Southern California spiny lobster fishery & Knowledge types \\
\hline Resource system & $\begin{array}{l}\text { Southern California coastal marine zone } \\
\text { Unclear system boundaries } \\
\text { High productivity } \\
\text { Large ecosystem } \\
\text { Predictable seasonality }\end{array}$ & $\begin{array}{l}\text { System - description of the resource system and functional } \\
\text { processes as related to the resource unit }\end{array}$ \\
\hline Resource units & $\begin{array}{l}\text { Lobsters } \\
\text { High economic value } \\
\text { Identifiable reproductive females } \\
\text { High mobility during recruitment } \\
\text { Low adult mobility } \\
\text { Slow growth rate }\end{array}$ & System - description of lobsters as a resource unit \\
\hline Governance & $\begin{array}{l}\text { Facilitated comanagement between stakeholders } \\
\text { Operational rules to be deliberated for fishing } \\
\text { Constitutional choice rules exist for policy-making } \\
\text { Marine protected areas exist }\end{array}$ & $\begin{array}{l}\text { System - describing the governance system characteristics and } \\
\text { functional processes }\end{array}$ \\
\hline \multirow[t]{2}{*}{ Actors } & $\begin{array}{l}\text { Six relevant actor groups }(\mathrm{C}, \mathrm{R}, \mathrm{E}, \mathrm{N}, \mathrm{M}, \mathrm{G}) \\
\text { Varied knowledge of SES between groups } \\
\text { Established social capital in groups } \\
\text { High actor group leadership }\end{array}$ & $\begin{array}{l}\text { System - identification of actor representatives and } \\
\text { characteristics on the comanagement committee and their } \\
\text { larger actor groups }\end{array}$ \\
\hline & $\begin{array}{l}\text { History of conflict in policy planning for marine protected } \\
\text { areas }\end{array}$ & $\begin{array}{l}\text { Target - actor perspectives, goals, and values; consensus on } \\
\text { the pursuit of normative sustainability goals }\end{array}$ \\
\hline \multirow[t]{2}{*}{ Action situations } & $\begin{array}{l}\text { Information sharing: Stakeholders share knowledge about SES } \\
\text { during comanagement meetings. }\end{array}$ & $\begin{array}{l}\text { System - description of interactive processes as well as } \\
\text { deliberative and knowledge sharing procedures }\end{array}$ \\
\hline & $\begin{array}{l}\text { Deliberation: Stakeholders deliberate policy pathways to } \\
\text { achieve group and collective goals. }\end{array}$ & $\begin{array}{l}\text { Transformative - reconciling trade-offs between different } \\
\text { actor goals and values through deliberation and information } \\
\text { sharing. Effective governance pathways can be identified. } \\
\text { Education occurs through information sharing. }\end{array}$ \\
\hline
\end{tabular}

sharing. For commercial fishers, decision-making may be influenced primarily by the economic value of the resource. However, the recreational, nonconsumptive, and environmental groups may endorse biophysical or socio-cultural values gained through benefits such as sense of place, recreational opportunity, intrinsic value, and community identity. If these values are not identified in a diagnosis of the system, their inclusion in an analysis of transformative knowledge generation in the policy recommendation process will be missed.

Expanding the diagnosis of ecosystem functioning in the socialecological systems framework

In addition to recognizing further values, use of the SESF by natural scientists is needed to expand diagnostic components for the resource system. Ecological drivers are not empirically investigated as well as social dynamics are in existing applications and literature. This can be attributed to a lack of contributions from the natural sciences in development and use of the framework (Vogt et al. 2015). Ecosystem characteristics (resource systems and resource units) have underlying supporting and regulating processes that may be influential in shaping system outcomes, particularly the provisioning of resources. These components should be included in the diagnosis and generation of knowledge that can inform sustainability. This enhances the potential to develop theory that includes ecological system drivers in SES interactions and outcomes. Learning from the ES concept, recognition of ecosystem functioning is pivotal among the common classification schemes (e.g., Millennium Ecosystem Assessment 2005, Haines-Young and Potschin 2012). In particular, the first and second operational stages of the ES cascade focus on biodiversity and ecological functions as important underlying foundations leading to ES and human wellbeing. Enhancing the diagnostic capacity of the SESF can be achieved by learning from how the ES concept recognizes ecosystem functioning as a core driver of SES outcomes.

The SESF diagnosis of the fishery places the resource unit (lobsters) as the focus of analyzing the ecological system. However, the ecological system consists of many species and ecological relationships that allow the system to function and lobsters to exist. Many of these ecological functions provide diverse benefits to the different stakeholder groups (Table 3). More specificity is needed for describing the resource system components beyond the second tier level of the framework. In addition, recognition of physical, chemical, and biological rules in ecosystem functioning may play a key role in diagnosing a system (Epstein et al. 2013, Vogt et al. 2015). Developing theory and analytical methods that integrate social and ecological system components can be done only with indepth component development on both sides of the SESF. Fully understanding the lobster fishery with existing theories requires this for an accurate 
assessment. Overall, managing natural resources will be more effective when influential social-ecological linkages can be diagnosed with a robust framework of components and can inform decision-making.

\section{Describing and analyzing social systems in ecosystem services} There is no standardized approach to analyzing the social system in ES research. The ES cascade stages are clear in the ecological system, but the social system and the governance feedback stage are less developed. There is no common set of social system components similar to the list of identified services and values. The identification of governance structures and their outcomes remains vague (Jacobs et al. 2013, Görg et al. 2015, Primmer et al. 2015). Social system analysis using ES is left to interpretation, which minimizes the benefits of using a common conceptual framework across cases for comparisons and theory generation. Thus, research on ES governance needs to be enhanced, with thought for developing common components for analysis (Bennett et al. 2015). A review of the different social system and governance analyses using ES would be useful to consolidate efforts. With intention for mutual learning, ES researchers can draw on the development of the SESF for social system analysis. The SESF has identified many components to diagnose social systems, particularly related to how institutions affect behavior and decision-making through empirically studied components.

Using ES, knowledge of the governance and institutional structures of the fishery remains vague, and relies on the use of other frameworks or knowledge to identify them. The main reason is the lack of explicit components for an assessment. This makes it difficult to produce system knowledge on the underlying structural social components that influence the Southern California spiny lobster fishery. There are no explicit linkages or components between governance and ecosystem functioning that can be used to identify specifics in our case. In contrast, target knowledge is more clearly facilitated through the identification of explicit values that can be associated with different stakeholders. The missing facilitation of system knowledge related to the fishery's governance hinders an effective analysis of the management plan with the ES concept.

\section{A common language and standardized framework for ecosystem services}

Various ES classification schemes exist and are used with, for example, MEA, TEEB, and Common International Classification of Ecosystem Services [CICES] (Bull et al. 2016). For example, MEA differentiates four ES categories (supporting, provisioning, regulating, cultural), while the CICES classification differentiates only three categories (provisioning, regulating, cultural). Regarding the ES cascade, there is no cohesive approach for how to apply the cascade as a step-by-step process. For each step, different literature builds the basis for the assessment (Table 2) because different groups of researchers (often with specific disciplines focusing on one step) focus on the specific steps with no standardization. An analysis using ES is typically not applied as a holistic conceptual framework to explain the whole SES. Consequently, findings are compartmentalized to specific steps and are hard to combine or compare. In contrast, the SESF has been suggested as a formalized structure that can build an ontology and common language for SES research, including guiding literature aimed at structuring comparable data (Frey and Cox 2015, Hinkel et al. 2015). Standardizing use of the concept should not limit the ES approach but generate knowledge that can be clearly communicated and compared across case studies (Haines-Young and Potschin 2014). Formalizing a guideline to add and interpret the relationships between nested components in the ES conceptual framework may be useful in this regard.

The general steps of the ES cascade are clear when implemented in our case study. There is a procedural flow from the Southern California coastal ecosystem and functions such as upwelling and biophysical parameters. This leads to the social system with the identification of ES, economic, and socio-cultural benefits gained by each stakeholder group as well as the derived well-being. Finally, the feedback loop is closed through deriving policy recommendations for the ES in the SES. However, the procedural steps or components for a more detailed analysis are not clear. As seen in Table 2, there is no clear way to compare specific components of governance in the analysis of the lobster comanagement committee or governance structure as done by the SESF. As a result, conclusions or transformative knowledge cannot be generated easily, transferred, or compared to other similar SES.

\section{Challenges and improvements in both approaches}

Common challenges in generating knowledge for sustainability exist in all SES research. For ES, manifold usage of the concept has led to a lack of cohesion between its multiple classification schemes, definitions, and aims. Since the publication of the MEA (2005), hundreds of yearly publications now include wide-ranging interpretations of the concept for different research and policy agendas (Chaudhary et al. 2015). Larger scale endeavors such as the Intergovernmental Panel on Biodiversity and Ecosystem Services also try to conceptualize the ES concept to bring on a common international policy agenda (Díaz et al. 2015). The ES concept has found its way to some national policy- and decisionmakers such as the Obama administration, which announced that ES must be considered in all federal decision-making (The White House 2015). Such broad usage has led ES to be considered a boundary object for sustainability (Abson et al. 2014). However, the different perspectives contest the possible uses of the ES concept, including monetary valuation and the role of the concept in supporting conservation initiatives (see discussion between Silvertown 2015, Schröter and van Oudenhoven 2016, and Wilson and Law (2016).

The SESF has yet to gain roots within a broader community of researchers. Most of its usage comes from researchers directly connected to its foundations. Literature on the framework has suggested many expansions to broaden its diagnostic scope, including ecologically (Vogt et al. 2015), in recognition of external political settings (Guevara et al. 2016), for application in diverse cases (Hinkel et al. 2015, Marshall 2015), and as a tool in sustainability science (Partelow 2016). While the framework is being pushed as a potential common SES language and formal SES ontology (Frey and Cox 2015, Hinkel et al. 2015), ontological consistency in current empirical applications is lacking (Thiel et al. 2015). While the framework continues to expand its use in contextual case diagnoses, it needs to reconcile broader and diverse engagement with maintaining the ontological consistency required to facilitate useful comparative analysis across cases. 
Lastly, both approaches lack empirical applications that demonstrate how they can be used to generate transformative knowledge. This aspect concludes the flow of knowledge as part of a holistic research process (Fig. 1). Although neither approach may have been intended for such ambitions, this has been considered an integral aspect of SES research. Nearly all SES approaches face difficulties in finding appropriate methodologies that use conceptual frameworks to interlink different types of data and engage society, as well as highlight and implement practical solutions. Large gaps exist between theory and practice in such research efforts, which often aim to be transdisciplinary but lack applied solutions beyond the scientific discourse (Zscheischler and Rogga 2015). Knowledge integration and mutual learning between existing scientific efforts can be a major step toward bridging the science-society gap.

\section{CONCLUSION}

We have analyzed and compared the ecosystem services concept and Ostrom's diagnostic social-ecological systems framework. We identified how each can generate system, target, and transformative knowledge to compare their contributions and ability to mutually learn from each other in SES research. Use of the ES concept facilitates ecocentric system knowledge. This is contrasted with how the SESF is used primarily to facilitate anthropocentric system knowledge. Concerning target knowledge, the ES concept is often used as a tool to facilitate coproduction and value trade-offs with stakeholders, whereas applying the SESF is descriptive and analytical in the diagnosis of actor behavior and decision-making processes. Lastly, both perspectives lack empirical applications that demonstrate how they can be used as academic tools to both generate and implement transformative knowledge in real-world cases. To address these gaps, we highlight compatibilities and mutual learning possibilities between them through understanding their strengths and weaknesses as well as their history and how they are used in research. It is increasingly necessary that the SES research community further unifies through boundary work if academic contributions are to match the pace at which informed solutions are needed for real-world sustainability challenges.

Responses to this article can be read online at: http://www.ecologyandsociety.org/issues/responses. $\mathrm{php} / 8524$

\footnotetext{
Acknowledgments:

We thank two anonymous reviewers whose comments greatly helped improve the content and quality of our paper. In addition, we thank João Garcia Rodrigues, Achim Schlüter, and Marion Glaser for comments on an earlier draft, which improved the manuscript substantially. KJW is funded by the Ministry of Science and Culture of Lower Saxony (MWK) Research Training "Interdisciplinary approach to functional biodiversity research'"(IBR) at the University of Oldenburg. SP is funded by the Leibniz Center for Tropical Marine Ecology (ZMT) and is additionally supported through Jacobs University and GLOMAR - Bremen International Graduate School for Marine Sciences. Both authors contributed
}

equally to this manuscript. The publication of this article was funded by the Open Access Fund of the Leibniz Association.

\section{LITERATURE CITED}

Abson, D. J., H. von Wehrden, S. Baumgärtner, J. Fischer, J. Hanspach, W. Härdtle, H. Heinrichs, A. M. Klein, D. J. Lang, P. Martens, and D. Walmsley. 2014. Ecosystem services as a boundary object for sustainability. Ecological Economics 103:2937. http://dx.doi.org/10.1016/j.ecolecon.2014.04.012

Addison, J., and R. Greiner. 2015. Applying the social-ecological systems framework to the evaluation and design of payment for ecosystem service schemes in the Eurasian steppe. Biodiversity and Conservation. http://dx.doi.org/10.1007/s10531-015-1016-3

Ban, N. C., L. S. Evans, M. Nenadovic, and M. Schoon. 2015. Interplay of multiple goods, ecosystem services, and property rights in large social-ecological marine protected areas. Ecology and Society 20(4):2. http://dx.doi.org/10.5751/es-07857-200402

Ban, N. C., M. Mills, J. Tam, C. C. Hicks, S. Klain, N. Stoeckl, M. C. Bottrill, J. Levine, R. L. Pressey, T. Satterfield, and K. M. A. Chan. 2013. A social-ecological approach to conservation planning: embedding social considerations. Frontiers in Ecology and the Environment 11:194-202. http://dx.doi.org/10.1890/110205

Bennett, D. E., and H. Gosnell. 2015. Integrating multiple perspectives on payments for ecosystem services through a socialecological systems framework. Ecological Economics 116:172181. http://dx.doi.org/10.1016/j.ecolecon.2015.04.019

Bennett, E. M., W. Cramer, A. Begossi, G. Cundill, S. Díaz, B. N. Egoh, I. R. Geijzendorffer, C. B. Krug, S. Lavorel, E. Lazos, L. Lebel, B. Martín-López, P. Meyfroidt, H. A. Mooney, J. L. Nel, U. Pascual, K. Payet, N. P. Harguindeguy, G. D. Peterson, A.-H. Prieur-Richard, B. Reyers, P. Roebeling, R. Seppelt, M. Solan, P. Tschakert, T. Tscharntke, B. L. Turner, P. H. Verburg, E. F. Viglizzo, P. C. L. White, and G. Woodward. 2015. Linking biodiversity, ecosystem services, and human well-being: three challenges for designing research for sustainability. Current Opinion in Environmental Sustainability 14:76-85. http://dx.doi. org/10.1016/j.cosust.2015.03.007

Binder, C. R., J. Hinkel, P. W. G. Bots, and C. Pahl-Wostl. 2013. Comparison of frameworks for analyzing social-ecological systems. Ecology and Society 18(4):26. http://dx.doi.org/10.5751/ es-05551-180426

Bodin, Ö., and B. I. Crona. 2009. The role of social networks in natural resource governance: What relational patterns make a difference? Global Environmental Change 19(3):366-374. http:// dx.doi.org/10.1016/j.gloenvcha.2009.05.002

Bohensky, E. L., and Y. Maru. 2011. Indigenous knowledge, science, and resilience: What have we learned from a decade of international literature on "integration"? Ecology and Society 16 (4):6. http://dx.doi.org/10.5751/es-04342-160406

Brandt, P., A. Ernst, F. Gralla, C. Luederitz, D. J. Lang, J. Newig, F. Reinert, D. J. Abson, and H. Von Wehrden. 2013. A review of transdisciplinary research in sustainability science. Ecological Economics 92:1-15. http://dx.doi.org/10.1016/j.ecolecon.2013.04.008 
Bull, J. W., N. Jobstvogt, A. Böhnke-Henrichs, A. Mascarenhas, N. Sitas, C. Baulcomb, C. K. Lambini, M. Rawlins, H. Baral, J. Zähringer, E. Carter-Silk, M. V. Balzan, J. O. Kenter, T. Häyhä, K. Petz, and R. Koss. 2016. Strengths, Weaknesses, Opportunities and Threats: a SWOT analysis of the ecosystem services framework. Ecosystem Services 17:99-111. http://dx.doi. org/10.1016/j.ecoser.2015.11.012

Chan, K. M. A., P. Balvanera, K. Benessaiah, M. Chapman, S. Díaz, E. Gómez-Baggethun, R. Gould, N. Hannahs, K. Jax, S. Klain, G. W. Luck, B. Martín-López, B. Muraca, B. Norton, K. Ott, U. Pascual, T. Satterfield, M. Tadaki, J. Taggart, and N. Turner. 2016. Opinion: Why protect nature? Rethinking values and the environment. Proceedings of the National Academy of Sciences of the United States of America 113(6):1462-1465. http:// dx.doi.org/10.1073/pnas. 1525002113

Chan, K. M., A. D. Guerry, P. Balvanera, S. Klain, T. Satterfield, and X. Basurto. 2012b. Where are cultural and social in ecosystem services? A framework for constructive engagement. BioScience 62(8):744-756. http://dx.doi.org/10.1525/bio.2012.62.8.7

Chan, K. M. A., T. Satterfield, and J. Goldstein. $2012 a$. Rethinking ecosystem services to better address and navigate cultural values. Ecological Economics 74:8-18. http://dx.doi. org/10.1016/j.ecolecon.2011.11.011

Chaudhary, S., A. McGregor, D. Houston, and N. Chettri. 2015. The evolution of ecosystem services: a time series and discoursecentered analysis. Environmental Science \& Policy 54:25-34. http://dx.doi.org/10.1016/j.envsci.2015.04.025

Comberti, C., T. F. Thornton, V. Wyllie de Echeverria, and T. Patterson. 2015. Ecosystem services or services to ecosystems? Valuing cultivation and reciprocal relationships between humans and ecosystems. Global Environmental Change 34:247-262. http:// dx.doi.org/10.1016/i.gloenvcha.2015.07.007

Daniel, T. C., A. Muhar, A. Arnberger, O. Aznar, J. W. Boyd, K. M. A. Chan, R. Costanza, T. Elmqvist, C. G. Flint, P. H. Gobster, A. Grêt-Regamey, R. Lave, S. Muhar, M. Penker, R. G. Ribe, T. Schauppenlehner, T. Sikor, I. Soloviy, M. Spierenburg, K. Taczanowska, J. Tam, and A. von der Dunk. 2012. Contributions of cultural services to the ecosystem services agenda. Proceedings of the National Academy of Sciences of the United States of America 109(23):8812-8819. http://dx.doi.org/10.1073/pnas.1114773109

Davies, K. K., K. T. Fisher, M. E. Dickson, S. F. Thrush, and R. Le Heron. 2015. Improving ecosystem service frameworks to address wicked problems. Ecology and Society 20(2):37. http://dx. doi.org/10.5751/es-07581-200237

de Groot, R. S., R. Alkemade, L. Braat, L. Hein, and L. Willemen. 2010. Challenges in integrating the concept of ecosystem services and values in landscape planning, management and decision making. Ecological Complexity 7(3):260-272. http://dx.doi. org/10.1016/j.ecocom.2009.10.006

Delgado-Serrano, M. del M., and P. Ramos. 2015. Making Ostrom's framework applicable to characterise social ecological systems at the local level. International Journal of the Commons 9(2):808-830. http://dx.doi.org/10.18352/ijc.567

Díaz, S., S. Demissew, J. Carabias, C. Joly, M. Lonsdale, N. Ash, A. Larigauderie, J. R. Adhikari, S. Arico, A. Báldi, A. Bartuska,
I. A. Baste, A. Bilgin, E. Brondizio, K. M. Chan, V. E. Figueroa, A. Duraiappah, M. Fischer, R. Hill, T. Koetz, P. Leadley, P. Lyver, G. M. Mace, B. Martin-Lopez, M. Okumura, D. Pacheco, U. Pascual, E. S. Pérez, B. Reyers, E. Roth, O. Saito, R. J. Scholes, N. Sharma, H. Tallis, R. Thaman, R. Watson, T. Yahara, Z. A. Hamid, C. Akosim, Y. Al-Hafedh, R. Allahverdiyev, E. Amankwah, S. T. Asah, Z. Asfaw, G. Bartus, L. A. Brooks, J. Caillaux, G. Dalle, D. Darnaedi, A. Driver, G. Erpul, P. EscobarEyzaguirre, P. Failler, A. M. M. Fouda, B. Fu, H. Gundimeda, S. Hashimoto, F. Homer, S. Lavorel, G. Lichtenstein, W. A. Mala, W. Mandivenyi, P. Matczak, C. Mbizvo, M. Mehrdadi, J. P. Metzger, J. B. Mikissa, H. Moller, H. A. Mooney, P. Mumby, H. Nagendra, C. Nesshover, A. A. Oteng-Yeboah, G. Pataki, M. Roué, J. Rubis, M. Schultz, P. Smith, R. Sumaila, K. Takeuchi, S. Thomas, M. Verma, Y. Yeo-Chang, and D. Zlatanova. 2015. The IPBES conceptual framework - connecting nature and people. Current Opinion in Environmental Sustainability 14:1-16. http:// dx.doi.org/10.1016/j.cosust.2014.11.002

Epstein, G., J. M. Vogt, S. K. Mincey, M. Cox, and B. Fischer. 2013. Missing ecology: integrating ecological perspectives with the social-ecological system framework. International Journal of the Commons 7(2):432-453. http://dx.doi.org/10.18352/ijc.371

Everard, M. 2015. Communicating ecosystem services. Ecosystem News.

Fagerholm, N., M. Torralba, P. J. Burgess, and T. Plieninger. 2016. A systematic map of ecosystem services assessments around European agroforestry. Ecological Indicators 62:47-65. http://dx. doi.org/10.1016/j.ecolind.2015.11.016

Fischer, J., T. A. Gardner, E. M. Bennett, P. Balvanera, R. Biggs, S. Carpenter, T. Daw, C. Folke, R. Hill, T. P. Hughes, T. Luthe, M. Maass, M. Meacham, A. V Norstrom, G. Peterson, C. Queiroz, R. Seppelt, M. Spierenburg, and J. Tenhunen. 2015. Advancing sustainability through mainstreaming a socialecological systems perspective. Current Opinion in Environmental Sustainability 14:144-149. http://dx.doi.org/10.1016/j.cosust.2015.06.002

Förster, J., J. Barkmann, R. Fricke, S. Hotes, M. Kleyer, S. Kobbe, D. Kübler, C. Rumbaur, M. Siegmund-Schultze, R. Seppelt, J. Settele, J. H. Spangenberg, V. Tekken, T. Václavík, and H. Wittmer. 2015. Assessing ecosystem services for informing landuse decisions: a problem-oriented approach. Ecology and Society 20(3):31. http://dx.doi.org/10.5751/es-07804-200331

Frey, U. J., and M. Cox. 2015. Building a diagnostic ontology of social-ecological systems. International Journal of the Commons 9(2):595-618. http://dx.doi.org/10.18352/ijc.505

Gadgil, M., F. Berkes, and C. Folke. 1993. Indigenous knowledge for biodiversity conservation. Ambio 22(2-3):151-156.

Görg, C., H. Keune, E. Primmer, and C. Schleyer. 2015. Good governance. In M. Potschin and K. Jax, editors. OpenNESS Ecosystem Service Reference Book. EC FP7 Grant Agreement no. 308428 .

Görg, C., J. H. Spangenberg, V. Tekken, B. Burkhard, D. Thanh Truong, M. Escalada, K. Luen Heong, G. Arida, L. V. Marquez, J. Victor Bustamante, H. Van Chien, T. Klotzbücher, A. Marxen, N. Hung Manh, N. Van Sinh, S. (Bong) Villareal, and J. Settele. 2014. Engaging local knowledge in biodiversity research: 
experiences from large inter- and transdisciplinary projects. Interdisciplinary Science Reviews 39(4):323-341. http://dx.doi. org/10.1179/0308018814z.00000000095

Grêt-Regamey, A., B. Weibel, F. Kienast, S.-E. Rabe, and G. Zulian. 2014. A tiered approach for mapping ecosystem services. Ecosystem Services 13:16-27. http://dx.doi.org/10.1016/j. ecoser.2014.10.008

Guevara, L. E. T., A. Schlüter, and M. C. Lopez. 2016. Collective action in a tropical estuarine lagoon: adapting Ostrom's SES framework to Ciénaga Grande de Santa Marta. International Journal of the Commons 10(1):1-29.

Hadorn, G. H., D. Bradley, C. Pohl, S. Rist, and U. Wiesmann. 2006. Implications of transdisciplinarity for sustainability research. Ecological Economics 60:119-128. http://dx.doi. org/10.1016/j.ecolecon.2005.12.002

Haines-Young, R., and M. Potschin. 2010. The links between biodiversity, ecosystem services and human well-being. Pages 110-139 in D. G. Raffaelli and C. L. J. Frid, editors. Ecosystem ecology: anew synthesis. Cambridge University Press, Cambridge. http://dx.doi.org/10.1017/cbo9780511750458.007

Haines-Young, R., and M. Potschin. 2012. Common International Classification of Ecosystem Services (CICES): Consultation on Version 4, August-December 2012. EEA Framework Contract No.

Haines-Young, R., and M. Potschin. 2014. The ecosystem approach as a framework for understanding knowledge utilisation. Environment and Planning C: Government and Policy 32(2):301-319. http://dx.doi.org/10.1068/c1329j

Hauck, J., C. Görg, R. Varjopuro, O. Ratamäki, J. Maes, H. Wittmer, and K. Jax. 2013. "Maps have an air of authority": potential benefits and challenges of ecosystem service maps at different levels of decision making. Ecosystem Services 4:25-32. http://dx.doi.org/10.1016/j.ecoser.2012.11.003

Hertz, T., and M. Schlüter. 2015. The SES-framework as boundary object to address theory orientation in social-ecological system research: the SES-TheOr approach. Ecological Economics 116:12-24. http://dx.doi.org/10.1016/j.ecolecon.2015.03.022

Hinkel, J., P. W. G. Bots, and M. Schlüter. 2014. Enhancing the Ostrom social-ecological system framework through formalization. Ecology and Society 19(3):51. http://dx.doi.org/10.5751/ es-06475-190351

Hinkel, J., M. E. Cox, M. Schlüter, C. R. Binder, and T. Falk. 2015. A diagnostic procedure for applying the social-ecological systems framework in diverse cases. Ecology and Society 20(1):32. http://dx.doi.org/10.5751/es-07023-200132

Jacobs, S., B. Haest, T. de Bie, G. Deliège, A. Schneiders, and F. Turkelboom. 2013. Biodiversity and ecosystem services. Pages 29 40 in S. Jacobs, N. Dendoncker, and H. Keune, editors. Ecosystem services. Elsevier. http://dx.doi.org/10.1016/b978-0-12-419964-4.00003-2

Jerneck, A., L. Olsson, B. Ness, S. Anderberg, M. Baier, E. Clark, T. Hickler, A. Hornborg, A. Kronsell, E. Lövbrand, and J. Persson. 2010. Structuring sustainability science. Sustainability Science 6(1):69-82. http://dx.doi.org/10.1007/s11625-010-0117$\underline{x}$
Jordan, A., and D. Russel. 2014. Embedding the concept of ecosystem services? The utilisation of ecological knowledge in different policy venues. Environment and Planning C: Government and Policy 32(2):192-207. http://dx.doi.org/10.1068/c3202ed

Karrasch, L., T. Klenke, and J. Woltjer. 2014. Linking the ecosystem services approach to social preferences and needs in integrated coastal land use management - a planning approach. Land Use Policy 38:522-532. http://dx.doi.org/10.1016/j. landusepol.2013.12.010

Leslie, H. M., X. Basurto, M. Nenadovic, L. Sievanen, and K. C. Cavanaugh. 2015. Operationalizing the social-ecological systems framework to assess sustainability. Proceedings of the National Academy of Sciences of the United States of America 112 (19):5979-5984. http://dx.doi.org/10.1073/pnas.1414640112

Liu, J., T. Dietz, S. R. Carpenter, C. Folke, M. Alberti, C. L. Redman, S. H. Schneider, E. Ostrom, A. N. Pell, J. Lubchenco, W. W. Taylor, Z. Ouyang, P. Deadman, T. Kratz, and W. Provencher. 2007. Coupled human and natural systems. Ambio 36(8):639-649. http://dx.doi.org/10.1579/0044-7447(2007)36[639: chans]2.0.co:2

Luederitz, C., E. Brink, F. Gralla, V. Hermelingermeier, M. Meyer, L. Niven, L. Panzer, S. Partelow, A.-L. Rau, R. Sasaki, D. J. Abson, D. J. Lang, C. Wamsler, and H. von Wehrden. 2015. A review of urban ecosystem services: six key challenges for future research. Ecosystem Services 14:98-112. http://dx.doi.org/10.1016/ j.ecoser.2015.05.001

Mace, G. M. 2014. Whose conservation? Science 345(6204):15581560 .

Marshall, G. R. 2015. A social-ecological systems framework for food systems research: accommodating transformation systems and their products. International Journal of the Commons 9(2):128. http://dx.doi.org/10.18352/ijc. 587

Martín-López, B., E. Gómez-Baggethun, M. García-Llorente, and C. Montes. 2014. Trade-offs across value-domains in ecosystem services assessment. Ecological Indicators 37:220-228. http://dx.doi.org/10.1016/j.ecolind.2013.03.003

McGinnis, M. D. 2011. Networks of adjacent action situations in polycentric governance. Policy Studies Journal 39(1):51-78. http://dx.doi.org/10.1111/j.1541-0072.2010.00396.x

McGinnis, M. D., and E. Ostrom. 2014. Social-ecological system framework: initial changes and continuing challenges. Ecology and Society 19(2):30. http://dx.doi.org/10.5751/es-06387-190230

Milcu, A. I., J. Hanspach, D. Abson, and J. Fischer. 2013. Cultural ecosystem services: a literature review and prospects for future research. Ecology and Society 18(3):44. http://dx.doi.org/10.5751/ es-05790-180344

Millennium Ecosystem Assessment. 2005. Ecosystems and human well-being: general synthesis. Washington, D.C., USA.

Mollinga, P. P. 2010. Boundary work and the complexity of natural resources management. Crop Science 50(Supplement 1): S-1-S-9. http://dx.doi.org/10.2135/cropsci2009.10.0570

Nassl, M., and J. Löffler. 2015. Ecosystem services in coupled social-ecological systems: closing the cycle of service provision 
and societal feedback. Ambio 44(8):737-749. http://dx.doi. org/10.1007/s13280-015-0651-y

Newell, B., C. L. Crumley, N. Hassan, E. F. Lambin, C. PahlWostl, A. Underdal, and R. Wasson. 2005. A conceptual template for integrative human-environment research. Global Environmental Change 15(4):299-307. http://dx.doi.org/10.1016/j.gloenvcha.2005.06.003

Orenstein, D. 2013. More than language is needed in valuing ecosystem services. BioScience 63(12):913-913. http://dx.doi. org/10.1525/bio.2013.63.12.17

Ostrom, E. 2005. Understanding institutional diversity. Princeton University Press, Princeton, New Jersey, USA.

Ostrom, E. 2007. A diagnostic approach for going beyond panaceas. Proceedings of the National Academy of Sciences of the United States of America 104(39):15181-15187. http://dx.doi. org/10.1073/pnas.0702288104

Ostrom, E. 2009. A general framework for analyzing sustainability of social-ecological systems. Science 325 (5939):419-422. http://dx.doi.org/10.1126/science.1172133

Ostrom, E., and M. Cox. 2010. Moving beyond panaceas: a multitiered diagnostic approach for social-ecological analysis. Environmental Conservation 37(04):451-463. http://dx.doi. org/10.1017/s0376892910000834

Partelow, S. 2015. Key steps for operationalizing social-ecological system framework research in small-scale fisheries: a heuristic conceptual approach. Marine Policy 51:507-511. http://dx.doi. org/10.1016/j.marpol.2014.09.005

Partelow, S. 2016. Coevolving Ostrom's social-ecological systems (SES) framework and sustainability science: four key co-benefits. Sustainability Science 11(3):399-410. http://dx.doi.org/10.1007/ s11625-015-0351-3

Partelow, S., and C. Boda. 2015. A modified diagnostic socialecological system framework for lobster fisheries: case implementation and sustainability assessment in Southern California. Ocean \& Coastal Management 114:204-217. http://dx. doi.org/10.1016/j.ocecoaman.2015.06.022

Primmer, E., P. Jokinen, M. Blicharska, D. N. Barton, R. Bugter, and M. Potschin. 2015. Governance of ecosystem services: a framework for empirical analysis. Ecosystem Services 16:158-166. http://dx.doi.org/10.1016/j.ecoser.2015.05.002

Reyers, B., R. Biggs, G. S. Cumming, T. Elmqvist, A. P. Hejnowicz, and S. Polasky. 2013. Getting the measure of ecosystem services: a social-ecological approach. Frontiers in Ecology and the Environment 11(5):268-273. http://dx.doi.org/10.1890/120144

Ruppert-Winkel, C., R. Arlinghaus, S. Deppisch, K. Eisenack, D. Gottschlich, B. Hirschl, M. Padmanabhan, K. Selbmann, R. Ziegler, and T. Plieninger. 2015. Characteristics, emerging needs, and challenges of transdisciplinary sustainability science: experiences from the German social-ecological. Ecology and Society 20(3):13. http://dx.doi.org/10.5751/es-07739-200313

Schleyer, C., C. Görg, J. Hauck, and K. J. Winkler. 2015. Opportunities and challenges for mainstreaming the ecosystem services concept in the multi-level policy-making within the EU. Ecosystem Services 16:174-181. http://dx.doi.org/10.1016/j. ecoser.2015.10.014
Scholte, S. S. K., A. J. A. van Teeffelen, and P. H. Verburg. 2015. Integrating socio-cultural perspectives into ecosystem service valuation: a review of concepts and methods. Ecological Economics 114:67-78. http://dx.doi.org/10.1016/j.ecolecon.2015.03.007

Scholz, R. 2011. Environmental literacy in science and society: from knowledge to decisions. Cambridge University Press, Cambridge. http://dx.doi.org/10.1017/cbo9780511921520

Scholz, R. W., and G. Steiner. 2015. The real type and ideal type of transdisciplinary processes: part I-theoretical foundations. Sustainability Science 10:527-544. http://dx.doi.org/10:527\&\#8211;544

Schoon, M., and S. van der Leeuw. 2015. The shift toward socialecological systems perspectives: insights into the human-nature relationship. Natures Sciences Sociétés 23:166-174. http://dx.doi. org/10.1051/nss/2015034

Schröter, M., and A. P. E. van Oudenhoven. 2016. Ecosystem services go beyond money and markets: reply to Silvertown. Trends in Ecology \& Evolution 31:333-334. http://dx.doi. org/10.1016/j.tree.2016.03.001

Seppelt, R., C. F. Dormann, F. V. Eppink, S. Lautenbach, and S. Schmidt. 2011. A quantitative review of ecosystem service studies: approaches, shortcomings and the road ahead. Journal of Applied Ecology 48(3):630-636. http://dx.doi.org/10.1111/j.1365-2664.2010.01952. $\underline{\mathrm{X}}$

Silvertown, J. 2015. Have ecosystem services been oversold? Trends in Ecology \& Evolution 30(11):641-648. http://dx.doi. org/10.1016/j.tree.2015.08.007

Spangenberg, J. H. 2011. Sustainability science: a review, an analysis and some empirical lessons. Environmental Conservation 38(3):275-287. http://dx.doi.org/10.1017/s0376892911000270

Spangenberg, J. H., C. von Haaren, and J. Settele. 2014. The ecosystem service cascade: further developing the metaphor. Integrating societal processes to accommodate social processes and planning, and the case of bioenergy. Ecological Economics 104:22-32. http://dx.doi.org/10.1016/j.ecolecon.2014.04.025

Star, S. L., and J. R. Griesemer. 1989. Institutional ecology, 'translations' and boundary objects: amateurs and professionals in Berkeley's Museum of Vertebrate Zoology, 1907-39. Social Studies of Science 19(3):387-420. http://dx.doi.org/10.1177/030$\underline{631289019003001}$

The Economics of Ecosystems \& Biodiversity (TEEB). 2010. The Economics of Ecosystems and Biodiversity: Ecological and Economic Foundations. P. Kumar, editor. Earthscan, London, UK and Washington, D.C., USA.

The White House. 2015. Incorporating natural infrastructure and ecosystem services in federal decision-making. Washington, D.C. USA. [online] URL: https://www.whitehouse.gov/blog/2015/10/07/ incorporating-natural-infrastructure-and-ecosystem-services-federaldecision-making

Thiel, A., M. E. Adamseged, and C. Baake. 2015. Evaluating an instrument for institutional crafting: how Ostrom's socialecological systems framework is applied. Environmental Science \& Policy 53:152-164. http://dx.doi.org/10.1016/j.envsci.2015.04.020 
Turnhout, E., C. Waterton, K. Neves, and M. Buizer. 2013. Rethinking biodiversity: from goods and services to "living with." Conservation Letters 6(3):154-161. http://dx.doi.org/10.1111/ j.1755-263x.2012.00307.x

Vogt, J. M., G. B. Epstein, S. K. Mincey, B. C. Fischer, and P. Mccord. 2015. Putting the "E" in SES: unpacking the ecology in the Ostrom social-ecological system framework. Ecology and Society 20(1):55. http://dx.doi.org/10.5751/es-07239-200155

Walker, B., and D. Salt. 2006. Resilience thinking: sustaining ecosystems and people in a changing world. Island Press, Washington, D.C. USA.

Wilson, K. A., and E. A. Law. 2016. How to avoid underselling biodiversity with ecosystem services: a response to Silvertown. Trends in Ecology \& Evolution 31:332-333. http://dx.doi. org/10.1016/j.tree.2016.03.002

Winkler, K. J., and K. A. Nicholas. 2016. More than wine: cultural ecosystem services in vineyard landscapes in England and California. Ecological Economics 124:86-98. http://dx.doi. org/10.1016/j.ecolecon.2016.01.013

Zscheischler, J., and S. Rogga. 2015. Transdisciplinarity in land use science - a review of concepts, empirical findings and current practices. Futures 65:28-44. http://dx.doi.org/10.1016/j.futures.2014.11.005 